\title{
ВПЛИВ АБІОТИЧНИХ ЧИННИКІВ ПІВДНЯ СТЕПОВОЇ ЗОНИ УКРАЇНИ НА ФОРМУВАННЯ ВРОЖАЙНОСТІ ЧЕРЕШНІ
}

\author{
Іванова І. Є., Сердюк М. Є.
}

\section{ВСТУП}

Дестабілізація погодних умов, забруднення атмосфери, загальне погіршення екологічної обстановки призвели до того, що рослини все більше піддаються пресингу широкого спектру стресорів. Негативний вплив часто перевищує поріг можливої адаптації рослин. Не дивно, що їхня захисна система сама потребує захисту. Особливо страждають багаторічні рослини, здатні накопичувати негативну інформацію. У результаті підвищується чутливість до стресорів та знижується врожайність ${ }^{1,2}$.

Усі стреси, які викликають напругу в біологічних системах, класифікують за комплексом негативних чинників на природні та антропогенні. Природні представлені двома групами: біотичні - це стреси, що мають біологічну природу та викликаються біологічними чинниками (мікробіологічні, фізіологічні та некрозо-ракові захворювання; пошкодження комахами або дія бур'янів в агроценозах); абіотичні - стреси, що викликаються чинниками неживої природи (температурний стрес, водний стрес; стрес, викликаний нестачею освітленості, тощо). Антропогенні стреси - це стреси, які є наслідками діяльності людини (виробництво хімічних, фізичних і біогенних, ущільнення грунту, дії, які викликають розвиток захворювань та послабляють стійкість до біотичних і абіотичних стресів, тощо.

Плодові культури відносяться до різних родів та видів. Кожна з них має велике розмаїття сортів, та всі вони мають особливі вимоги до умов навколишнього середовища.

Черешню вирощують більше ніж у 40 країнах, щорічне світове виробництво плодів культури становить понад 1450 тис т. Основними постачальниками є Німеччина, Італія, Франція, США ${ }^{3,4}$.

\footnotetext{
${ }^{1}$ Наумов А.О., Лимар А.О. Способи підвищення адаптивних здатностей рослин кавуна до негативних абіотичних чинників Південного Степу. Вісник аграрної науки. 2019. № 9(798). С. 21-28. DOI : 10.31073/agrovisnyk201909-03.

${ }^{2}$ Correia S., Schouten R., Silva Ana P., Gonçalves B. Factors Affecting Quality and Health Promoting Compounds during Growth and Postharvest Life of Sweet Cherry (Prunus avium L.). Frontiers in Plant Science. 2017. № 8. P. 2166. DOI : 10.3389/fpls.2017.02166.

${ }^{3}$ Витковский В.Л. Вишня и черешня. Плодовые растения мира. Санкт-Петербург : Лань, 2003. C. $204-227$.

${ }^{4}$ Wenden B., Mariadassou M. Sweet cherry phenology in the context of climate change: A systems biology approach. Acta horticulturae. 2017. № 1162. P. 31-38. DOI : 10.17660/ActaHortic.2017.1162.6. 
На території України промислове вирощування черешні зосереджено у Південній степовій підзоні. Плоди цієї культури користуються великою популярністю і займають одне з провідних місць у споживчому кошику. Вирощування черешні в садівничих господарствах Південної зони $€$ економічно вигідним, що пов'язано 3 отриманням фінансових ресурсів від продажу першої високоякісної плодової продукції5.

Кліматичні умови Південної степової зони України вважаються цілком сприятливими для промислового вирощування черешні $\mathrm{i}$ характеризуються сумою активних температур у межах $2200-3400^{\circ} \mathrm{C}$, середньою багаторічною сумою річних опадів - 475 мм, середньою річною вологістю повітря - 73\%, тривалістю вегетаційного періоду 170-240 днів, максимумом позитивних температур $-+41{ }^{0} \mathrm{C}$, негативних - мінус $31^{\circ} \mathrm{C}$.

Однак в умовах зміни клімату, особливо протягом останнього десятиліття, почастішали періоди несприятливого температурного впливу як у зимовий, так і в ранньовесняний періоди, істотно зменшилася кількість опадів. Середньобагаторічне значення гідротермічного коефіцієнту (ГТК) за період активної вегетації дорівнює 0,8 із коливанням у межах значень від 0,6 до 1,1 залежно від місяця. Отже, в умовах сьогодення садівництво даного регіону розвивається в посушливих умовах. Така характерна для регіону недостатня природня вологозабезпеченість в критичні періоди вегетації у сукупності 3 повітряною посухою може викликати незворотні зміни у дерев $\mathrm{i}$, як наслідок, призведе до зниження врожайності.

Проблемні питання садівництва, що виникають у зв'язку 3 кліматичними змінами i прогресуючим опустелюванням сільськогосподарський земель південних регіонів України розглядалися у роботах багатьох учених ${ }^{6,7,8}$.

Так, академік НААН України О.О. Іващенко 9 , 10 повідомляє, що у зв'язку з глобальними змінами клімату вже сьогодні в зоні ризику знаходяться понад 55\% площ орних земель нашої країни, а це вся зона Степу. Відзначено переміщення меж кліматичних зон за останні

\footnotetext{
${ }^{5}$ Галузева програма розвитку садівництва України на період до 2025 року. Київ, 2008. 76 с.

${ }^{6}$ Сердюк М.Е., Расторгуев А.Б. Оценка влияния погодных факторов на урожайность яблони в условиях Южной степной зоны Украины. Плодоводство. 2013. Т. 25. С. 341-347.

${ }^{7}$ Кіщак О.А. Наукові основи промислової культури черешні в Лісостепу України : автореф. дис. ... д-ра с.-г. наук : 06.01.07. Київ, 2014. 36 с.

${ }^{8}$ Bublyk M.O., Fryziuk L.A., Levchuk L.M. Fruit crop production distribution in Ukraine: A research note. Chemistry and Chemical Biology: Methodologies and Applications / ed. R. Joswik, A.A. Dalinkevich. Toronto, 2014. P. 207-214.

${ }^{9}$ Иващенко А. Будущее Украины - в глобальной системе производителей продовольствия. Gazeta. $Z n$. Ua. вебсайт. URL : http://gazeta.zn.ua/LAW/budushee_ukrainy_v_globalnoy_sisteme_proizvoditeley _prodovolstviya html (дата звернення: 22.07.2019).

${ }^{10}$ Иващенко А. Калахари - украинская Степь. Gazeta.zn.ua : вебсайт. URL : http:/gazeta.Zn.ua/ ECOLOGY/kalahari_ukrainskaya_step_klimaticheskie_izmeneniya_nesut_realnuyu_opasnost_poteri_dlya zemledeliy.html (дата звернення: 22.07.2019).
} 
десятиріччя. У Південному Степу (Херсонська та Запорізька області) вже реально проявляються ознаки опустелювання.

Учені Укргідрометцентру ${ }^{11}$ зазначають, що глобальні зміни клімату призведуть до суттєвої зміни умов вирощування плодових культур, що вплине на рівень їх урожайності.

3 погляду на такі екологічні зміни, найважливішою та вельми актуальним завданням $\epsilon$ вивчення залежності процесу формування врожайності плодів від абіотичних чинників. Вирішення цього завдання має не лише теоретичне, а й практичне значення, оскільки дає змогу об'єктивно прогнозувати масу майбутнього врожаю і може бути базою для комп'ютерного моделювання врожайності плодових культур.

Метою досліджень було наукове обгрунтування впливу абіотичних чинників на врожайність черешні в умовах Південної степової підзони України та створення математичної моделі для прогнозування врожайності культури на підставі виявлених стресових чинників.

Дослідження проводилися впродовж 11 послідовних вегетаційних періодів з 2008 по 2018 р. у межах Мелітопольського району Запорізької області. Цей регіон уважається основним у вирощуванні черешні в України. Розташований він у Південній степовій підзоні України. У ході експерименту використано метеорологічні дані, що надані метеостанцією м. Мелітополя, Україна.

Агрофон на дослідних ділянках протягом усіх дослідних років задовольняв вимогам агротехніки. Накопичення вологи в грунті відбувається переважно восени, частково - взимку і ранньою весною. Грунтом дослідних ділянок, на яких вирощується культура, є чорнозем південний легкосуглинковий. Грунтоутворююча порода - лес.

У вивченні знаходилося 33 сорти черешні, які за терміном достигання поділені на три групи: перша група - сорти раннього терміну достигання: Світ Ерліз, Мерчант, Бігаро Бурлат, Рубінова рання, Валерій Чкалов, Казка, Забута; друга група - сорти середнього терміну достигання: Кордія, Октавія, Винка, Первисток, Темп, Улюблениця Туровцева, Талісман, Ділема, Мелітопольська чорна, Оріон, Червнева рання, Дачниця, Простір; третя група - сорти пізнього терміну достигання: Каріна, Регіна, Міраж, Крупноплідна, Удівітельна, Зодіак, Сюрприз, Колхозниця, Космічна, Празднічна, Анонс, Темпоріон, Меотида.

Для досягнення мети нами було проведено кореляційний та регресійний аналіз: визначено силу кореляційних зв'язків між агрокліматичними показниками та врожайністю культури; встановлено комплекс погодних чинників, які суттєво впливають на врожайність черешні; отримано рівняння залежності середньої врожайності черешні

\footnotetext{
11 Адаменко Т. Без паніки: кліматичні зміни можуть виявитися корисними для сільського господарства. Український тиждень. 2012. № 29(246). С. 28-31. URL : https://m.tyzhden.ua/ publication/55863 (дата звернення: 22.07.2019).
} 
від стресових чинників, які допоможуть спрогнозувати досліджуваний параметр за дії об’єктивних стресових чинників оточуючого середовища.

Розрахунок моделей урожайності черешні у зв'язку 3 погодними чинниками проводили за схемою, яка докладно описана у наших попередніх публікаціях ${ }^{12,13}$.

\section{1. Аналіз урожайності плодів черешні \\ в умовах Південної степової підзони України}

Урожайність уважається однією з основних господарсько-біологічних ознак сорту. Передусім вона визначається генотипом, але також у чималому ступені залежить від таких абіотичних чинників, як погодні умови в різні періоди росту рослин і рівень застосовуваної агротехніки.

Результати одинадцятирічних досліджень дають можливість стверджувати, що середня врожайність черешні, яка вирощена в умовах аналізованого регіону, знаходилася на рівні 8,71 т/га (табл. 1).

Таблиця 1

Урожайність черешні, т/га (2008-2018 рр.), $\bar{x} \pm s \bar{x}, \mathrm{n}=5$

\begin{tabular}{|c|c|c|c|c|}
\hline \multirow{2}{*}{$\begin{array}{c}\text { Рік } \\
\text { досліджень }\end{array}$} & \multicolumn{3}{|c|}{ Урожайність, т/га } & \multirow{2}{*}{$\begin{array}{c}\text { Сортова } \\
\text { варіація в } \\
\text { межах року, } \\
\mathrm{V}_{\mathrm{C}}, \% \\
\end{array}$} \\
\hline & середня & Min & $\max$ & \\
\hline 2008 & $8,89 \pm 0,62$ & 7,90 & 9,89 & 6,9 \\
\hline 2009 & $2,51 \pm 0,27$ & 2,00 & 2,79 & 10,9 \\
\hline 2010 & $16,13 \pm 0,56$ & 15,10 & 16,79 & 3,5 \\
\hline 2011 & $8,51 \pm 0,70$ & 7,60 & 9,50 & 8,2 \\
\hline 2012 & $7,04 \pm 2,93$ & 3,90 & 11,89 & 41,5 \\
\hline 2013 & $15,57 \pm 0,37$ & 15,19 & 16,18 & 2,4 \\
\hline 2014 & $3,66 \pm 0,31$ & 3,09 & 4,10 & 8,3 \\
\hline 2015 & $9,49 \pm 0,59$ & 8,39 & 10,00 & 6,3 \\
\hline 2016 & $6,23 \pm 0,46$ & 5,50 & 6,90 & 7,4 \\
\hline 2017 & $4,26 \pm 0,39$ & 3,70 & 4,69 & 9,1 \\
\hline 2018 & $13,57 \pm 0,78$ & 12,39 & 14,30 & 5,7 \\
\hline Середнє значення & $8,71 \pm 4,59$ & 2,00 & 16,79 & 10,0 \\
\hline $\begin{array}{l}\text { Середня варіація } \\
\text { за роками } \mathrm{V}_{\mathrm{P}}, \%\end{array}$ & 54,8 & - & - & - \\
\hline $\mathrm{HIP}_{05}$ & 0,79 & - & - & - \\
\hline
\end{tabular}

\footnotetext{
${ }^{12}$ Serdyuk M., Stepanenko D., Kurchev S. The study of mass loss intensity of plum fruit during storage. Eastern-European Journal of Enterprise Technologies. 2016. Vol. 1/10. № 79. P. 42-48.

13 Регресійний аналіз залежності урожайності вишні від гідротермічних факторів в умовах мультиколінеарності / В. Малкіна та ін. Наукові горизонти. 2019. № 11(84). С. 51-60. DOI : 10.33249/2663-2144-2019-84-11-51-60.
} 
Найменший рівень отриманого врожаю зафіксовано у сорту Удівітельна (2,00 т/га) урожаю 2009 р. Вона була нижчою за середнє сортове значення на 77,0\%. Максимальний рівень урожаю $(16,79$ т/га) був у сорту Анонс у 2010 р. При цьому перевищення над середнім сортовим значенням становило 92,8\% (табл. 1).

Найбільшу цінність для промислового виробництва представляють сорти, що поєднують високі врожаї та їх стабільність ${ }^{14}$. Як показник стабільності сортів до впливу метеорологічних умов різних років вирощування був використаний коефіцієнт варіації V. Відомо, що за значень коефіцієнту варіації менше $10 \%$ варіативність вибірки вважається неістотною або низькою, за значень від 10\% до $20 \%$ середньою, вище $20 \%$ - істотною або сильною ${ }^{15}$.

У результаті проведених досліджень установлено, що врожайність черешні неістотно варіювала залежно від сорту та істотно - залежно від умов року вирощування. Так, середня мінливість урожайності різних сортів черешні в межах року досліджень становила $10 \%$ із варіюванням від 2,4\% у 2013 р. до 10,9\% у 2009 р. Виняток становив 2012 р., коли зафіксовано високу сортову варіативність урожайності черешні (табл. 1). Натомість для всіх аналізованих сортів черешні була встановлена висока мінливість урожайності за роками досліджень зі середнім коефіцієнтом кореляції майже 55\%. Такі отримані результати свідчать про домінування впливу погодних чинників над сортовими особливостями у процесі формування врожаю плодів черешні.

Для остаточного підтвердження домінуючого впливу абіотичних чинників на формування урожайності черешні було проведено двофакторний дисперсійний аналіз (рис. 1). Як було зазначено вище, рівень агротехніки на всіх дослідних ділянках був однаковим та задовольняв усім вимогам культури, тому його не ураховували як окремий фактор.

Отримані результати констатують, що частка впливу погодних умов у роки досліджень (фактор А) є максимальною та становить 94,97\%. Другим фактором за впливовістю була взаємодія чинників АВ із часткою впливу 4,11\%. Вплив сортових особливостей (фактор В) був неістотним. Його частка впливу становила $0,11 \%$.

Таким чином, установлена варіабельність урожайності у досліджуваної групи сортів черешні зумовлена більшою мірою впливом абіотичних чинників і меншою - сортовими особливостями культури.

\footnotetext{
${ }^{14}$ Multicriteria Optimization of Quality Indicators of Sweet Cherry Fruits of Ukrainian Selection During Freezing and Storage / I. Ivanova et al. Modern Development Paths of Agricultural Production. Trends and Innovations : Conference proceedings / ed. V. Nadykto. 2019. P. 707-717. DOI : 10.1007/978-3-030-14918-5.

${ }^{15}$ Effect of Living Mulch on Chlorophyll Index, Leaf Moisture Content and Leaf Area of Sweet Cherry (Prunus avium.L.) / T. Gerasko et al. Modern Development Paths of Agricultural Production. Trends and Innovations : Conference proceedings / ed. V. Nadykto. 2019. P. 681-688. DOI : 10.1007/978-3-030-14918-5. 


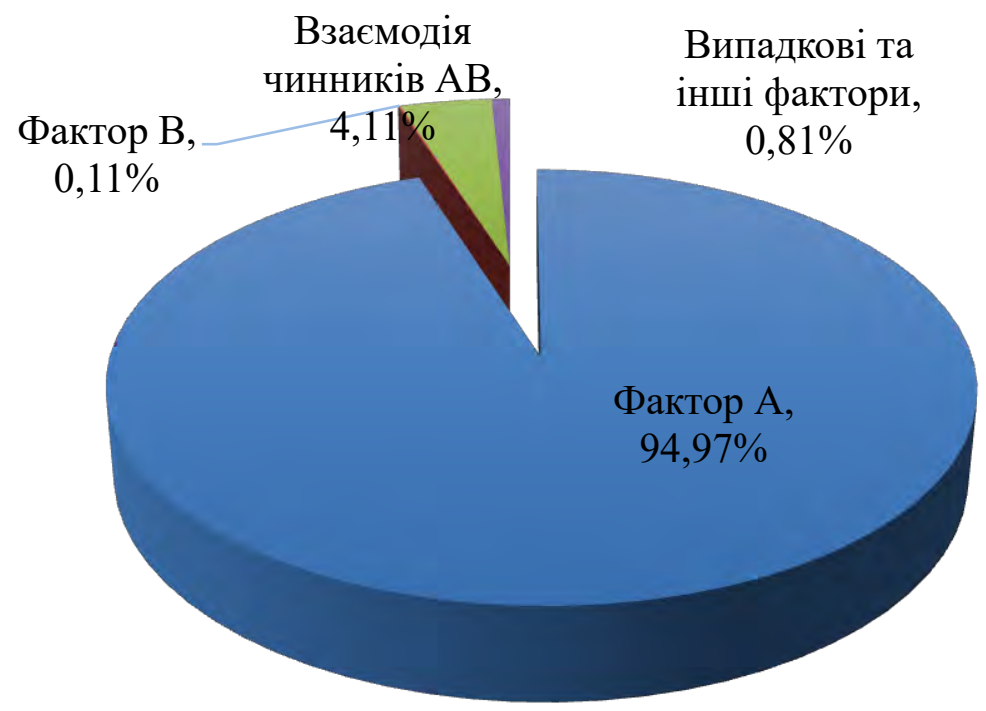

Рис. 1. Частка впливу чинників на рівень урожайності черешні, \%: фактор А - погодні умови у роки досліджень, фактор В - сорт, AВ - взаємодія чинників А і В, випадкові та інші фактори

\section{2. Оцінка впливу абіотичних чинників на формування врожайності черешні}

Для поглибленого аналізу реакції черешні на зовнішні лімітуючі фактори нами був використаний множинний регресійний аналіз. Він дає змогу коректно визначити, які ознаки, в яку фазу онтогенезу і на який лімітуючий фактор середовища реагує. Знання про характер впливу метеорологічних чинників середовища на біологічні системи в різні періоди онтогенезу відкриває великі можливості для оптимізації як сільськогосподарського виробництва, так і галузей зберігання та консервування плодів.

Під час формування багатофакторної моделі врожайності черешні у зв'язку 3 погодними умовами використовували функцію лінійної залежності

$$
Y=a_{0}+a_{1} X_{1}+a_{2} X_{2}+\cdots+a_{n} X_{n},
$$

де $Y$ - досліджувана ознака (відгук),

$X$ - факторні ознаки,

$n$ - число факторних ознак.

Для вирішення даного рівняння як невідомі були вибрані значущі кліматичні чинники, що лімітують урожайність. Усього було досліджено 202 чинники. Вони ураховувалися у такі фенологічні фази: період спокою, початок вегетації, період цвітіння, формування і дозрівання плодів, кінець вегетації. 
Для визначення більш значущих чинників був проведений кореляційний аналіз. За його результатами встановлено, що врожайність черешні корелює з багатьма погодними чинниками. Для 78 із них установлений кореляційний зв'язок середньої сили. Для 9 чинників (табл. 2) установлено сильний зв'язок.

Таблиця 2

Результати кореляційного аналізу впливу погодних чинників на врожайність черешні (2008-2018 pp.)

\begin{tabular}{|c|c|c|c|c|c|}
\hline № & Показник & $\begin{array}{c}\text { Коефіцієнт } \\
\text { кореляції }\end{array}$ & № & Показник & $\begin{array}{c}\text { Коефіцієнт } \\
\text { кореляції }\end{array}$ \\
\hline $\mathrm{X}_{1}$ & $\begin{array}{c}\text { Середні з мінімальних } \\
\text { температур повітря } \\
\text { квітня }\end{array}$ & 0,76 & $\mathrm{X}_{5}$ & $\begin{array}{c}\text { Кількість днів 3 } \\
\text { опадами в період } \\
\text { цвітіння }\end{array}$ & $-0,80$ \\
$\mathrm{X}_{2}$ & $\begin{array}{c}\text { Середні з мінімальних } \\
\text { температур повітря } \\
\text { травня }\end{array}$ & 0,72 & $\mathrm{X}_{6}$ & $\begin{array}{c}\text { Сума опадів в період } \\
\text { цвітіння }\end{array}$ & $-0,74$ \\
\hline $\mathrm{X}_{3}$ & $\begin{array}{c}\text { Сума активних } \\
\text { температур за } \\
\text { вегетаційний період } \\
\text { (до збору плодів) }\end{array}$ & 0,72 & $\mathrm{X}_{7}$ & $\begin{array}{c}\text { Гідротермічний } \\
\text { коефіцієнт у період } \\
\text { цвітіння }\end{array}$ & $-0,75$ \\
\hline $\mathrm{X}_{4}$ & $\begin{array}{c}\text { Загальна кількість днів } \\
\text { з опадами за грудень }\end{array}$ & 0,74 & $\mathrm{X}_{8}$ & $\begin{array}{c}\text { Середні з мінімальних } \\
\text { температур повітря в } \\
\text { період цвітіння }\end{array}$ & $-0,68$ \\
\hline $\mathrm{X}_{9}$ & \multicolumn{2}{|c|}{ Середня з максимальних температур повітря за березень } & $-0,68$ \\
\hline
\end{tabular}

До таких чинників відносять рівень середніх із максимальних значень температур за березень. Отримані дані (рис. 2) дають можливість констатувати, що показник протягом років коливається у межах значень 6,0-13,0 ${ }^{\circ} \mathrm{C}$. Із наведених даних видно, що в березні 2014 та 2017 pp. зафіксовано підвищення середніх із максимальних значень температур. Ці ж роки характеризуються низьким рівнем урожайності культури. Отриманню високого рівня врожаю черешні (12,99-16,16 т/га) сприяють значення середніх із максимальних значень температур за березень у діапазоні $6-8,3^{\circ} \mathrm{C}$, що були зафіксовані у 2012, 2013, 2016, 2018 pp. Отже, дуже ранній початок весни, який супроводжується високими температурами повітря, негативно впливає на рівень майбутнього врожаю черешні. Це пояснюється тим, що в умовах Південної степової підзони України дуже часто після березневого підвищення температури відбувається різке зниження ії рівня, аж до заморозків, у квітні, а інколи й у травні ${ }^{16}$.

\footnotetext{
${ }^{16}$ Урожайність черешні залежно від кліматичних умов років вирощування / І. Іванова та ін. Вісник аграрної науки Причорномор'я. 2019. Вип. 3(103). С. 61-70. DOI : 10.31521/2313-092X/2019-3(103)-8. 


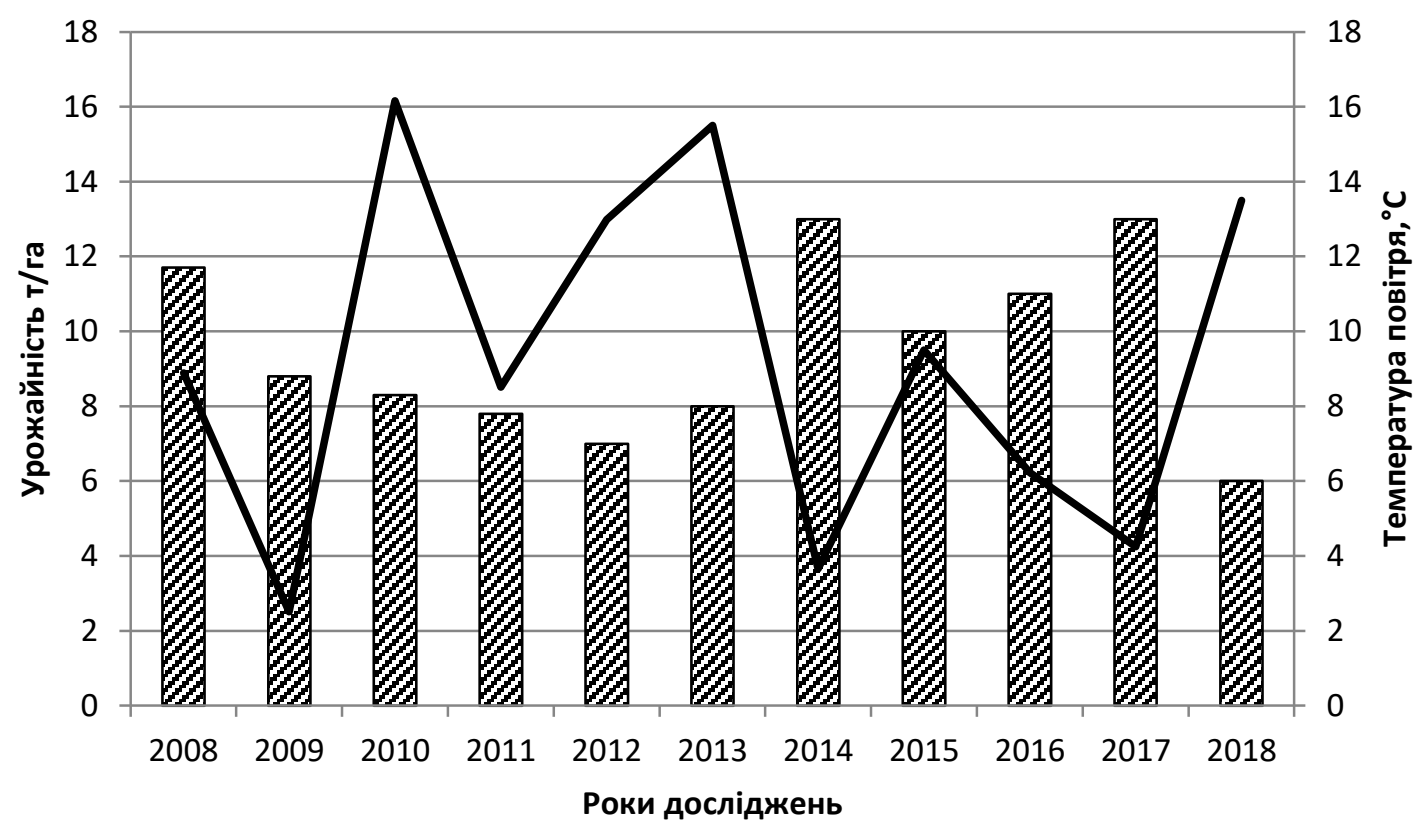

\# середня з максимальних значень температур повітря за березень, 든

—урожайність,т/га

\section{Рис. 2. Урожайність та середня з максимальних значень температур за березень, 2008-2019 pp.}

Наступним стресовим фактором $є$ середні з мінімальних температур квітня та травня (рис. 3). Із наведених даних видно, що в квітні відбувається зниження мінімальних температур нижче $-2^{\circ} \mathrm{C}(2009,2014$, 2016 та 2017 рр.). Ці ж роки характеризуються низьким рівнем урожайності культури. Негативно на врожайності черешні позначаються й низькі мінімальні температури травня. Натомість чим вищими $\epsilon$ мінімальні температури цього періоду, тим вищою $є$ врожайність. На думку деяких учених, це пов'язано з тим, що у квітні, коли дерева вийшли 3 вимушеного спокою, різкий перепад температур по роках створює стресові умови та веде до зниження врожаїв кісточкових культур. Також у травні, коли відбувається часткове цвітіння та дозрівання плодів, останні можуть бути ушкоджені низькими температурами ${ }^{17}$.

Серед досліджених погодних чинників сильний вплив на врожайність черешні мав також температурний режим під час цвітіння культури (рис. 4). На підставі отриманих результатів ми маємо можливість стверджувати, що стабільний температурний режим із високими середніми мінімальними температурами під час цвітіння підвищує рівень урожайності черешні. Так, у 2012 та 2013 рр. за максимальних

\footnotetext{
17 Бублик М.О. Методологічні та технологічні основи підвищення продуктивності сучасного садівництва. Київ : Нора-прінт, 2005. 286 с.
} 
значень середніх мінімальних температур під час цвітіння врожайність становила 12,99 т/га та 15,5 т/га відповідно. Винятком із визначеної тенденції є показники врожайності 2010 та 2018 pp.

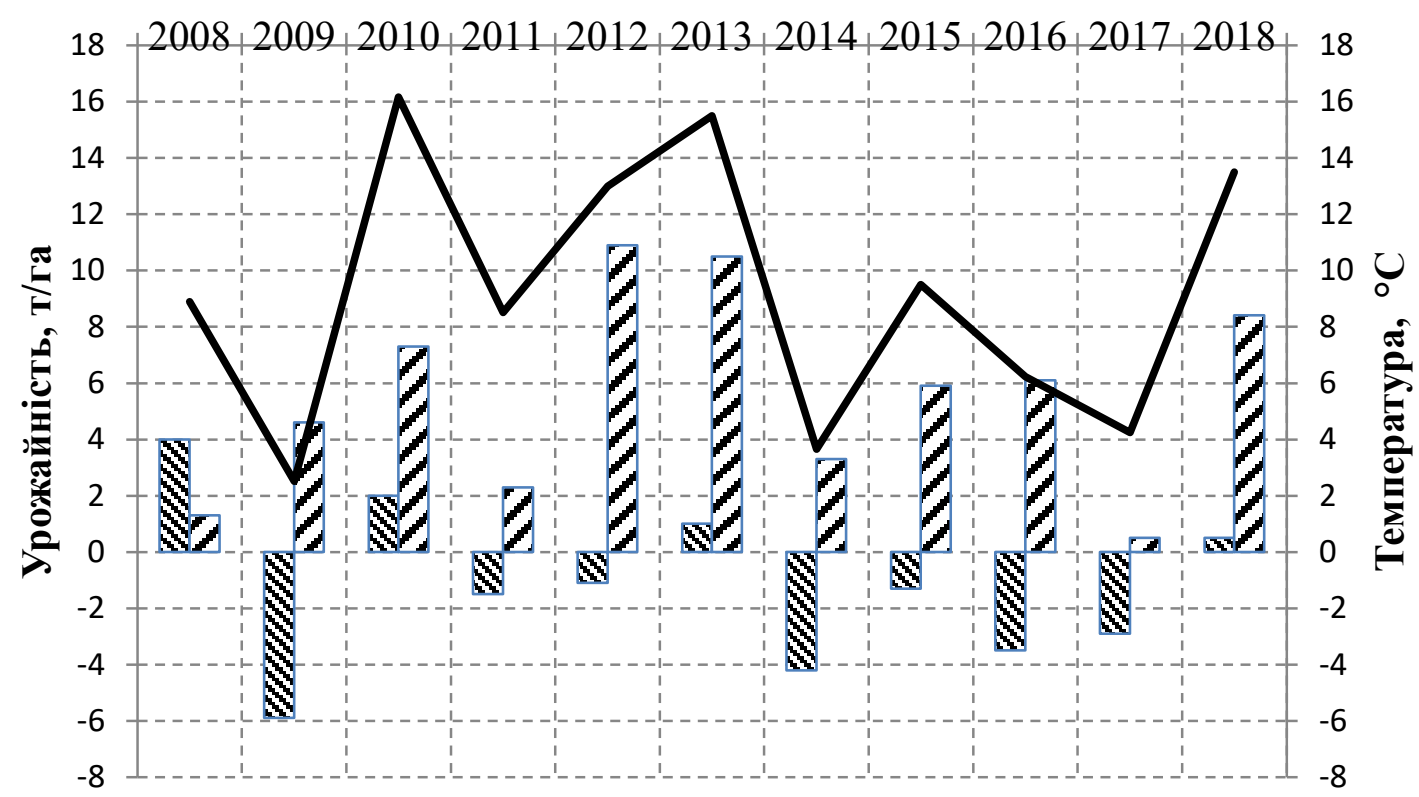

середня 3 мінімальних температур квітня, ${ }^{\circ} \mathrm{C}$

Рис. 3. Урожайність черешні та значення середніх із мінімальних температур повітря квітня та травня, 2008-2018 pp.

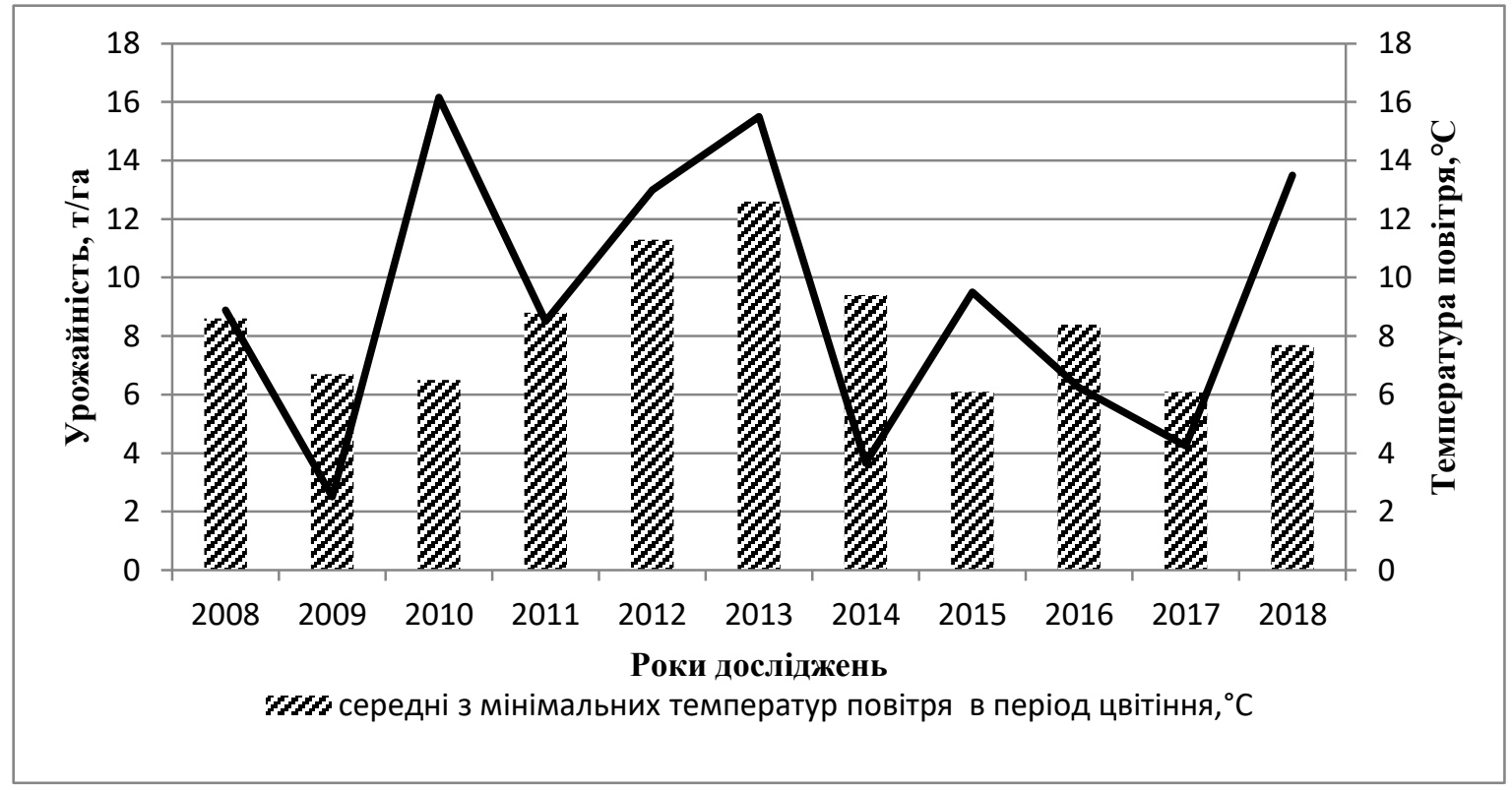

Рис. 4. Урожайність та середня з мінімальних значень температур у період цвітіння, 2008-2019 рр. 
Показник суми активних температур $є$ важливим для визначення сумарної потреби рослин у теплі. Отримані дані (рис. 5) дають можливість констатувати, що сума активних температур вище $10^{\circ} \mathrm{C}$ (САТ 10) за вегетаційний період (до збирання плодів) протягом років коливається у межах значень $726,6-968,8^{\circ} \mathrm{C}$. Показники САТ 10 у діапазоні від $726,6^{\circ} \mathrm{C}$ до $839,2^{\circ} \mathrm{C}$ негативно вплинули на врожайність черешні у 2009, 2014, 2016, 2017 pр. (врожайність становила 2,51-6,23 т/га). Максимальний рівень урожайності культури в діапазоні $13,5-16,16$ т/га встановлений за значень САТ 10 від $850,5^{\circ} \mathrm{C}$ у 2010 , 2012, 2013 та 2018 pp.

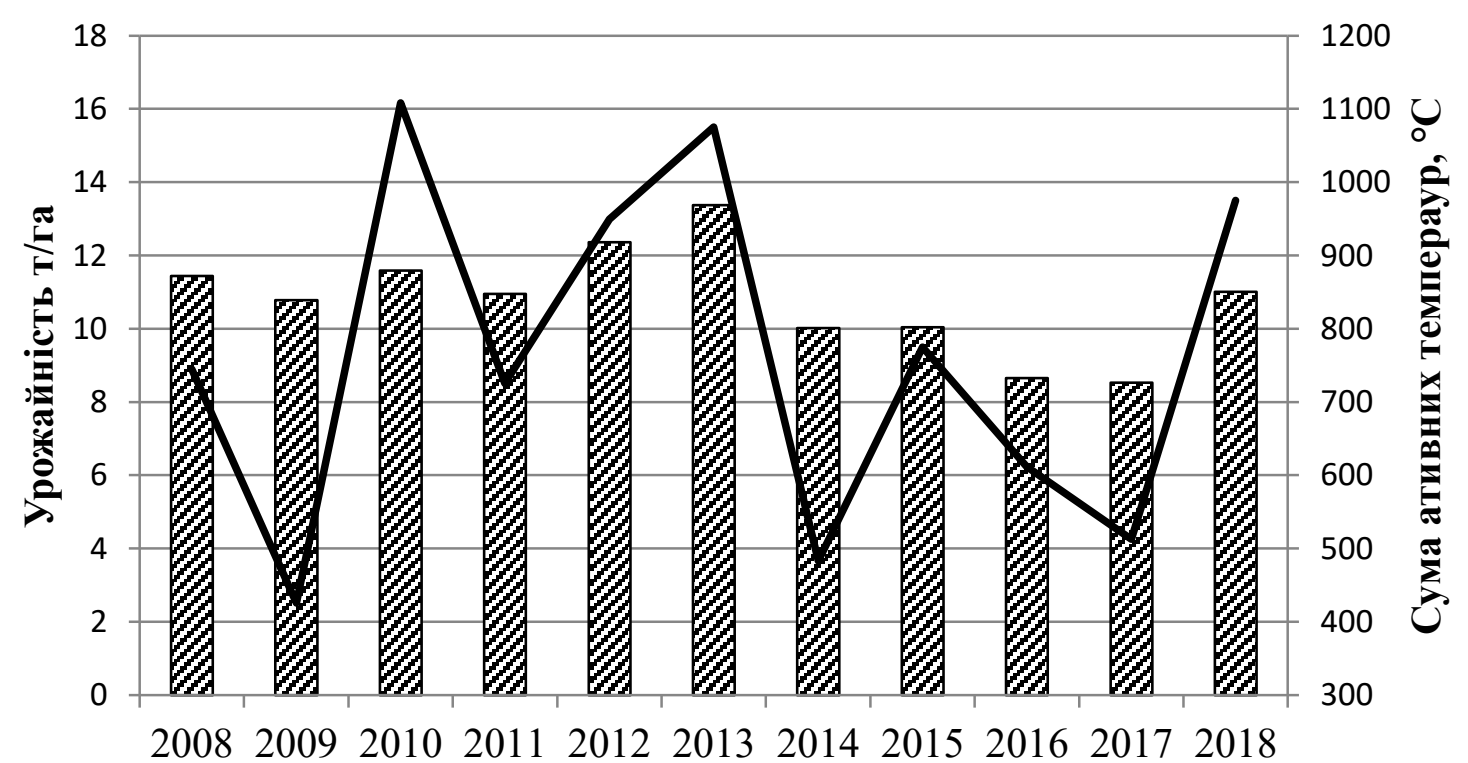

Роки досліджень

ш сума активних температур за вегетаційний період, ${ }^{\circ} \mathrm{C}$

—урожайність черешні,т/га

\section{Рис. 5. Сума активних температур за вегетаційний період (до збору плодів) та врожайність черешні, 2008-2018 pp.}

Серед інших чинників, що визначають урожайність плодових культур, найважливіше місце належить водному режиму рослин. Основним джерелом надходження вологи в грунт є опади.

Графічну інтерпретацію впливу загальної кількості днів з опадами як за грудень, так і в період цвітіння на врожайність черешні наведено на рис. 6. Із наведених даних видно, що роки з підвищеною кількістю днів 3 опадами в грудні від 13 до 18 діб (2010, 2012, 2013, 1018 рр.) характеризуються високим рівнем урожайності культури. 3 рис. 6 
видно, що зниження кількості днів 3 опадами в період цвітіння супроводжується зростанням урожайності черешні. У 2010, 2012, 2013, 1018 рр., коли зафіксовано максимальну кількість днів з опадами в грудні (від 13 до 18 діб) та мінімальну кількість днів з опадами за період цвітіння від 0 до 3 діб, спостерігаються високі показники врожайності (рис. 6).

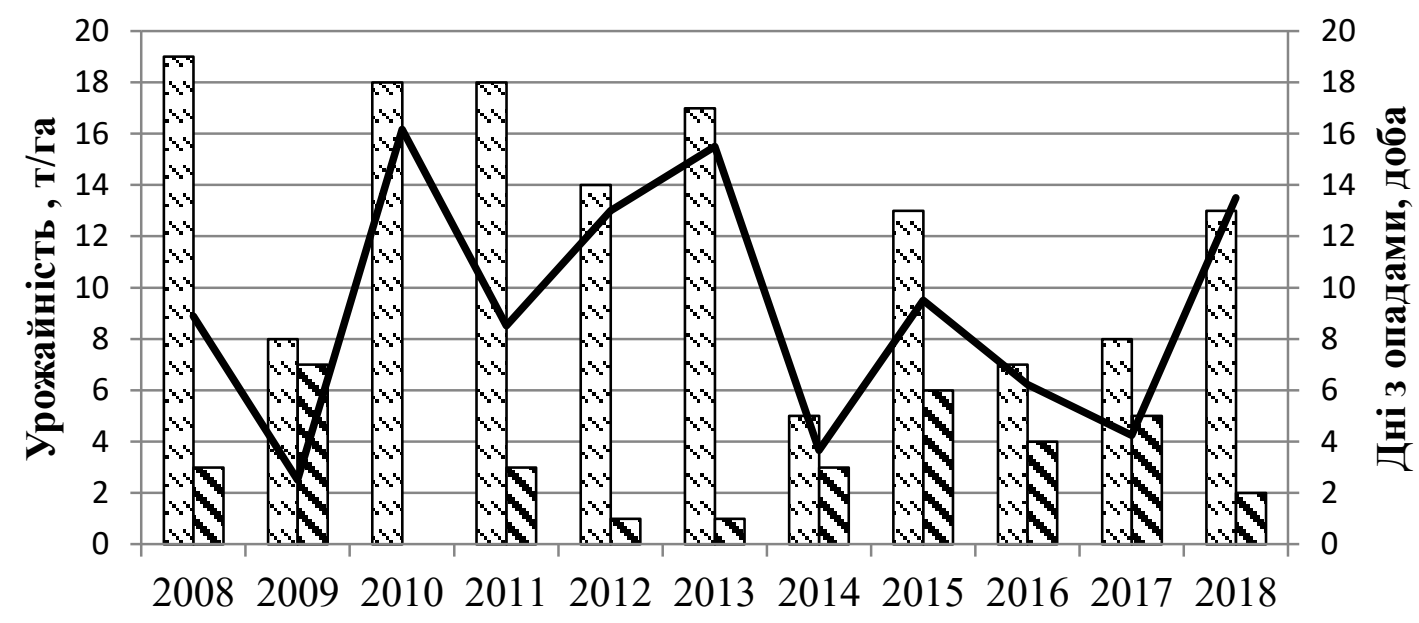

Роки досліджень

खзагальна кількість днів з опадами за грудень,доба

$\mathbf{W}$ загальна кількість днів з опадами в період цвітіння,доба

一урожайність , т/га

\section{Рис. 6. Загальна кількість днів з опадами за грудень, у період цвітіння та врожайність черешні, 2008-2018 pp.}

Аналізом впливу значень показника суми опадів у період цвітіння на врожайність черешні визначено, що коливання параметра за роками досліджень відбувається в діапазоні від 0 до 40,1 мм (рис. 7). Максимальну врожайність досліджуваної культури визначено в роки 3 мінімальним значенням суми опадів у період цвітіння. Так, для 2010 та 2013 рр., коли врожайність становила 15,5-16,6 т/га, опадів у період цвітіння не спостерігалося. Причиною зниження врожайності за збільшення показників як суми опадів, так і кількості днів з опадами у період цвітіння може бути гальмування або повне зупинення процесу опилення дерев ${ }^{18,19}$.

\footnotetext{
${ }^{18}$ Богданюк О.В. Оцінка впливу чинників на врожайність плодово-ягідних культур у контексті ефективного управління садівництвом. Молодий вчений. 2016. № 11. С. 555-558. URL : http://nbuv.gov.ua/UJRN/ Tmolv_2016_11_130 (дата звернення: 22.07.2019).

${ }^{19}$ The effect of climatic conditions on sweet cherry fruit treated with plant growth regulators / S. Zeman ed al. Journal of Food Agriculture and Environment. 2013. № 11(2). P. 521-528.
} 


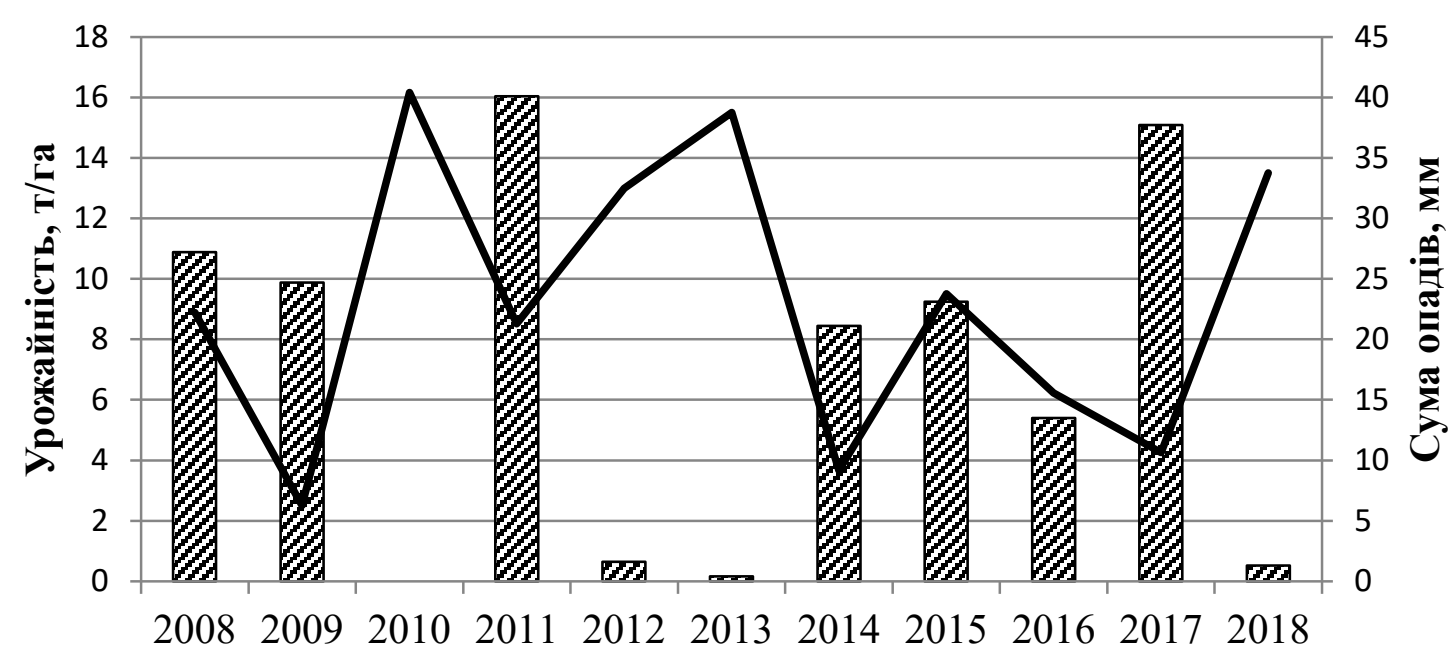

Роки досліджень

\# сума опадів в період цвітіння,мм - -урожайність,т/га

Рис. 7. Сума опадів у період цвітіння

та врожайність черешні, 2008-2018 рр.

Узагальненою характеристикою тепло- i вологозабезпеченості певного періоду вегетації рослин $є$ гідротермічний коефіцієнт (ГТК). У наших дослідженнях (рис. 8) ГТК за роки досліджень у період цвітіння черешні коливався у межах 0-2,76.

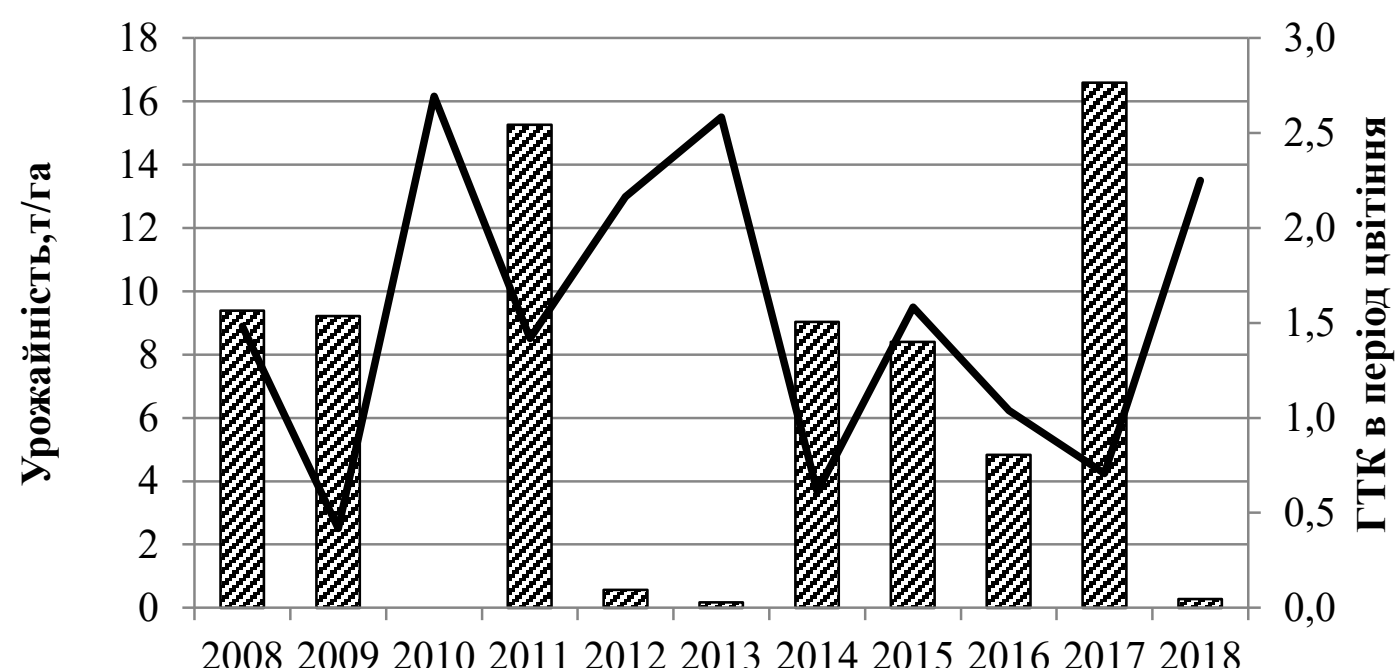

Роки досліджень

щ ГТК в період цвітіння — -урожайність,т/га

Рис. 8. Гідротермічний коефіціснт (ГТК) у період цвітіння та врожайність черешні, 2008-2018 рр. 
Аналіз отриманих даних за 11 років досліджень дав змогу визначити, що в 2010, 2012, 2013, 2016 та 2018 рр., які характеризувалися високими показниками врожайності, ГТК у період цвітіння був нижче 1 та коливався в інтервалі $0-0,8$. Урожайність черешні у зазначені роки була максимальною за весь період експерименту в інтервалі 12,99-16,16 т/га (винятком $є$ показник урожайності у 2016 р. - 6,23 т/га).

Для чинників, що мають сильний вплив на врожайність черешні (табл. 2) у зазначених та схожих умовах, було проведено множинний кореляційний та регресійний аналіз, за результатами отримано таке рівняння залежності середньої врожайності черешні від стресових чинників (із вірогідністю 95\%).

$$
\begin{gathered}
Y=26,48859+0,79268 X_{1}+1,22482 X_{2}-0,02425 X_{3}+0,27284 X_{4^{-}} \\
0,57072 X_{5}+0,56934 X_{6}-5,43041 X_{7}-0,27930 X_{8}+0,28554 X_{9} .
\end{gathered}
$$

При цьому коефіцієнт множинної кореляції $\mathrm{R}=0,997$, коефіцієнт детермінації $\mathrm{R}^{2}=0,995$, скоригований коефіцієнт детермінації - 0,959, критерій $\mathrm{F}(9,1)=27,15$, рівень значущості - 0,0027, стандартна похибка оцінки - 0,969.

Оцінка наведеного вище рівняння довела, що у цілому воно $є$ статистично значущим, але окремі коефіцієнти рівняння $\epsilon$ незначущими $\left(\mathrm{t}_{\text {розр. }}<\mathrm{t}_{\text {табл. }}\right)$. Під час проведення обгрунтованого відбору чинників для включення у рівняння нами були виявлені та виключені 3 рівняння фактори, які незначною мірою впливають на результат, а також колінеарні фактори (в яких парний коефіцієнт кореляції не менше 0,7$)^{20,21,22}$.

Підсумкове рівняння для прогнозування врожайності черешні залежно від стресових погодних чинників має вигляд:

$$
\mathrm{Y}=5,998424+1,068352 \mathrm{X}_{1}+0,810361 \mathrm{X}_{2} \text {, }
$$

де $\mathrm{Y}$ - урожайність черешні, т/га, $\mathrm{X}_{1}$ - середні 3 мінімальних температур повітря квітня та $\mathrm{X}_{2}$ - середні з мінімальних температур повітря травня.

Використані комп'ютерні програми MS Office Excel 2007 та пакет Statistica 6 дали можливість вибрати параметри як статистично значимі у межах представленої моделі ${ }^{14}$.

При цьому коефіцієнт множинної кореляції $\mathrm{R}=0,958$, коефіцієнт детермінації $\mathrm{R}^{2}=0,918$, скоригований коефіцієнт детермінації - 0,897 ,

\footnotetext{
${ }^{20}$ Growth and yield of the sweet cherry (prunus avium 1.) as affected by training system / M. Radunic et al. African Journal Of Biotechnology. 2011. Vol. 10. № 24. P. 4901-4906.

${ }_{21}$ Куприенко Н.В., Пономарева О.А., Тихонов Д.В. Статистические методы изучения связей. Кореляционно-регресионный анализ. Санкт-Петербург : Политехн. ун-т, 2008. 118 с.

${ }^{22}$ Харчук Т.В. Передумови забезпечення стійкого розвитку підприємств садівництва. Ефективна економіка. 2017. № 11. URL : http://www.economy.nayka.com.ua/?op=1\&z=5891 (дата звернення: 22.07.2019). 
критерій $\mathrm{F}(2,8)=44,89$, рівень значущості - 0,00004, стандартна похибка оцінки - 1,5352 .

\section{ВИСНОВКИ}

Виходячи 3 вищевикладеного, за допомого методів математичної статистики було отримано сільськогосподарську оцінку впливу абіотичних чинників Південного степу України на врожайність черешні:

1. Найбільша середня урожайність плодів була зафіксована для сорту пізнього строку достигання Анонс (16,79 т/га) у 2010 р. та найменша для сорту пізнього строку достигання Удівітельна (2 т/га) у 2009 р. У результаті проведених досліджень установлено, що врожайність черешні неістотно варіювала залежно від сорту та істотно - залежно від умов року вирощування.

2. Результатами двохфакторного аналізу показано, що на формування врожаю черешні вирішальний вплив $(94,97 \%)$ мають погодні умови років досліджень (фактор А). Вплив сортових особливостей (фактор В) $\epsilon$ неістотним. Його частка впливу становить лише $0,11 \%$.

3. Під час проведення кореляційного аналізу було встановлено сильний лінійний кореляційний зв'язок між дев'ятьма погодними факторами для черешні (r від $-0,68$ до 0,76) та показниками врожайності культури.

4. На основі проведеного множинного кореляційно-регресійного аналізу було побудовано лінійну регресійну модель, яка дасть можливість спрогнозувати врожайність черешні залежно від впливу абіотичних чинників оточуючого середовища: $\mathrm{Y}=5,998424+1,068352 \mathrm{X}_{1}+$ $+0,810361 \mathrm{X}_{2}$. Дану математичну модель можна використовувати у будьякому регіоні зі схожими кліматичними умовами.

\section{АНОТАЦІЯ}

Дестабілізація погодних умов, забруднення атмосфери, загальне погіршення екологічної обстановки у Південній степовій підзоні України призвели до підвищення чутливості черешні до стресорів та зниження іiі врожайності. Метою наших досліджень було наукове обгрунтування впливу абіотичних чинників на врожайність черешні в умовах Південної степової підзони України та створення математичної моделі для прогнозування врожайності культури на підставі виявлених стресових чинників.

У результаті проведених одинадцятирічних досліджень установлено, що врожайність черешні істотно варіювала залежно від умов вирощування (частка впливу - 94,97\%) та неістотно - залежно від сорту (частка впливу $-0,11 \%$ ). 
Проведення кореляційного аналізу дало змогу визначити дев'ять погодних чинників, що мають сильний як прямий, так і обернений лінійний кореляційний зв'язок з урожайністю черешні $(\mathrm{r}=0,76 \ldots-0,80)$. Використання функції лінійної залежності $\mathrm{Y}=\mathrm{a}_{0}+\mathrm{a}_{1} \mathrm{X}_{1}+\mathrm{a}_{2} \mathrm{X}_{2}+\ldots+\mathrm{anXn}$ дало змогу сформувати багатофакторну модель: $\mathrm{Y}=5,998424+$ $+1,068352 \mathrm{X}_{1}+0,810361 \mathrm{X}_{2}$. Розроблення останньої дало можливість спрогнозувати врожайність черешні залежно від впливу стресових чинників оточуючого середовища.

\section{ЛІТЕРАТУРА}

1. Наумов А.О., Лимар А.О. Способи підвищення адаптивних здатностей рослин кавуна до негативних абіотичних чинників Південного Степу. Вісник аграрної науки. 2019. № 9(798). С. 21-28. DOI : 10.31073/agrovisnyk201909-03.

2. Factors Affecting Quality and Health Promoting Compounds during Growth and Postharvest Life of Sweet Cherry (Prunus avium L.) / S. Correia et al. Frontiers in Plant Science. 2017. № 8. P. 2166. DOI : 10.3389/ fpls.2017.02166.

3. Витковский В.Л. Вишня и черешня. Плодовые растения мира. Санкт-Петербург : Лань, 2003. С. 204-227.

4. Wenden B., Mariadassou M. Sweet cherry phenology in the context of climate change: A systems biology approach. Acta horticulturae. 2017. № 1162. P. 31-38. DOI : 10.17660/ActaHortic.2017.1162.6.

5. Галузева програма розвитку садівництва України на період до 2025 року. Київ, 2008. 76 с.

6. Сердюк М.Е., Расторгуев А.Б. Оценка влияния погодных факторов на урожайность яблони в условиях Южной степной зоны Украины. Плодоводство. 2013. Т. 25. С. 341-347.

7. Кіщак О.А. Наукові основи промислової культури черешні в Лісостепу України : автореферат. дис. ... д-ра с.-г. наук : 06.01.07. Київ, 2014. $36 \mathrm{c}$.

8. Bublyk M.O., Fryziuk L.A., Levchuk L.M. Fruit crop production distribution in Ukraine: A research note. Chemistry and Chemical Biology: Methodologies and Applications / ed. R. Joswik, A.A. Dalinkevich. Toronto, 2014. P. 207-214.

9. Иващенко А. Будущее Украины - в глобальной системе производителей продовольствия. Gazeta. Zn. Ua : вебсайт. URL : http://gazeta.zn.ua/LAW/budushee_ukrainy_v_globalnoy_sisteme_proizvodit eley prodovolstviya html (дата звернення: 22.07.2019).

10. Иващенко А. Калахари - украинская Степь. Gazeta.zn.ua : вебсайт. URL : http://gazeta.Zn.ua/ECOLOGY/kalahari_ukrainskaya_step_ 
klimaticheskie_izmeneniya_nesut_realnuyu_opasnost_poteri_dlya_zemledeli y.html (дата звернення: 22.07.2019).

11. Адаменко Т. Без паніки: кліматичні зміни можуть виявитися корисними для сільського господарства. Український тиждень. 2012. № 29(246). C. 28-31. URL : https://m.tyzhden.ua/publication/55863 (дата звернення: 22.07.2019).

12. Serdyuk M., Stepanenko D., Kurchev S. The study of mass loss intensity of plum fruit during storage. Eastern-European Journal of Enterprise Technologies. 2016. Vol. 1/10. № 79. P. 42-48.

13. Регресійний аналіз залежності урожайності вишні від гідротермічних чинників в умовах мультиколінеарності / В. Малкіна а ін. Наукові горизонти. 2019. № 11(84). C. 51-60. DOI : 10.33249/2663-21442019-84-11-51-60.

14. Multicriteria Optimization of Quality Indicators of Sweet Cherry Fruits of Ukrainian Selection During Freezing and Storage / I. Ivanova et al. Modern Development Paths of Agricultural Production. Trends and Innovations : Conference proceedings / ed. V. Nadykto. 2019. P. 707-717. DOI : 10.1007/978-3-030-14918-5.

15. Effect of Living Mulch on Chlorophyll Index, Leaf Moisture Content and Leaf Area of Sweet Cherry (Prunus avium.L.) / T. Gerasko et al. Modern Development Paths of Agricultural Production. Trends and Innovations : Conference proceedings / ed. V. Nadykto. 2019. P. 681-688. DOI : 10.1007/ 978-3-030-14918-5.

16. Урожайність черешні залежно від кліматичних умов років вирощування / I. Іванова та ін. Вісник аграрної науки Причорномор'я. 2019. Вип. 3(103). С. 61-70. DOI : 10.31521/2313-092X/2019-3(103)-8.

17. Бублик М.О. Методологічні та технологічні основи підвищення продуктивності сучасного садівництва. Київ : Нора-Принт, 2005. 286 с.

18. Богданюк О.В. Оцінка впливу чинників на урожайність плодовоягідних культур в контексті ефективного управління садівництвом. Молодий вчений. 2016. № 11. C. 555-558. URL : http://nbuv.gov.ua/UJRN/ Tmolv_2016_11_130 (дата звернення: 22.07.2019).

19. The effect of climatic conditions on sweet cherry fruit treated with plant growth regulators / S. Zeman ed al. Journal of Food Agriculture and Environment. 2013. № 11(2). P. 521-528.

20. Growth and yield of the sweet cherry (prunus avium 1.) as affected by training system / M. Radunic et al. African Journal Of Biotechnology. 2011. Vol. 10. № 24. P. 4901-4906.

21. Куприенко Н.В., Пономарева О.А., Тихонов Д.В. Статистические методы изучения связей. Кореляционнорегресионный анализ. СанктПетербург : Политехн. ун-т, 2008. 118 с. 
22. Харчук Т.В. Передумови забезпечення стійкого розвитку підприємств садівництва. Ефективна економіка. 2017. № 11. URL : $\mathrm{http} / / / \mathrm{www}$. economy.nayka.com.ua/?op=1\&z=5891 (дата звернення: 22.07.2019).

\section{Information about authors:}

Ivanova I. Ye.,

Candidate of Agricultural Sciences, Associate Professor at the Department of Horticulture,

Viticulture and Biochemistry Dmytro Motornyi Tavria State Agrotechnological University 18, Bogdan Khmelnitsky ave., Melitopol, Zaporizhzhya region, 72310, Ukraine Serdyuk M. Ye., Doctor of Technical Sciences (D. Sc.), Associate Professor, Professor at the Department of Food Technology and Hotel and Restaurant Business

Dmytro Motornyi Tavria State Agrotechnological University 18, Bogdan Khmelnitsky ave., Melitopol, Zaporizhzhya region, 72310, Ukraine 